\title{
Giant Basal Cell Carcinoma - a Case Report
}

\author{
Igor KAPETANOVIĆ1, Vesna RELJIĆ1 , Martina BOSIĆ³, Svetlana POPADIĆ1, 2 \\ ${ }^{1}$ Clinic of Dermatovenereology, Clinical Center of Serbia, Belgrade, Serbia \\ ${ }^{2}$ Department of Dermatovenereology, School of Medicine, University of Belgrade, Belgrade, Serbia \\ ${ }^{3}$ Institute of Pathology, School of Medicine, University of Belgrade, Belgrade, Serbia \\ *Correspondence: Igor Kapetanović, E-mail: igor.kapetanovic@hotmail.com \\ UDC 616.5-006.6-07/-08
}

\begin{abstract}
Basal cell carcinoma is the most common form of cutaneous cancer. In majority of cases it is locally invasive with slow growth, ranging in size from a couple of milimeters to a couple of centimeters and located primarily on sunexposed regions. Giant basal cell carcinoma, defined as a tumor that is larger than $5 \mathrm{~cm}$ in diameter, is a very rare type of cutaneous malignancy accounting for $0.5-1 \%$ of all basal cell carcinomas. We present a case of a $74-y e a r-$ old man with a $17 \times 14 \mathrm{~cm}$ giant basal cell carcinoma in the right supraclavicular region. Detailed history revealed that the lesion had started as a papule 15 years before presentation. Despite its growth, the lesion was neglected until admission. Histological examination of skin lesion confirmed superficial and focally infiltrative types of basal cell carcinoma. Electron radiotherapy was administered with 54 Gy total dose delivered in 20 daily fractions which resulted in healing of lesions and adequate response. Thus, definitive radiotherapy can be just as effective as excision when the criteria are met.
\end{abstract}

Key words: Carcinoma, Basal Cell; Diagnosis; Neoplasm Metastasis; Skin; Radiotherapy; Biopsy; Treatment Outcome; Case Reports

\section{Introduction}

Basal cell carcinoma (BCC) is the most common form of cutaneous cancer. Most cases are locally invasive, indolent, characterized by slow growth, rare metastasis, located predominantly on ultraviolet (UV) exposed areas such as the head and neck (in $80-85 \%$ of cases) and on the trunk (roughly only $10 \%$ ) (1). Caucasians over the age of 40 are the most affected group (2). The majority of BCCs range from a couple of millimeters to a couple of centimeters (mean size of $11.7 \mathrm{~mm} \pm 5.9$ $\mathrm{mm}$ ), with surgical excision being the preferred method of treatment leading to a 5 -year cure rate of $95 \%$ (3). In rare instances, basal cell carcinomas can be larger in size leading to a potentially more aggressive clinical course and difficulties in opting for the appropriate therapeutic modality. According to the American Joint Committee on Cancer, tumors with a diameter larger than $5 \mathrm{~cm}$ are defined as Giant Basal Cell Carcinoma (GBCC) (4). The incidence of this rare variant has been reported to be $0.5 \%-1 \%(5)$. Some authors think that a diameter greater than 10 $\mathrm{cm}$ should be the cutoff value for GBCC (6). When the maximum diameter is more than 20 $\mathrm{cm}$, the term Super Giant Basal Cell Carcinoma can be used and, to the best of our knowledge, there are only 10 reported cases in the literature $(7,8)$.

\section{Case Report}

We report a case of a 74-year-old male with an extensive histopathologically verified basal cell carcinoma that slowly progressed over the course of 15 years on the right supraclavicular region of the shoulder. The lesion started in 2003 as an erythematous papule that was neglected for many years. The patient was examined for the first time in 2008 when he was diagnosed to have a suspicious basal cell carcinoma and/or discoid erythematous lupus and he was treated with local corticosteroids, antibiotics and $5 \%$ fluorouracil cream with no improvement. The lesion was afterwards biopsied and histopathologic examination confirmed superficial type of basal cell carcinoma; however, further 


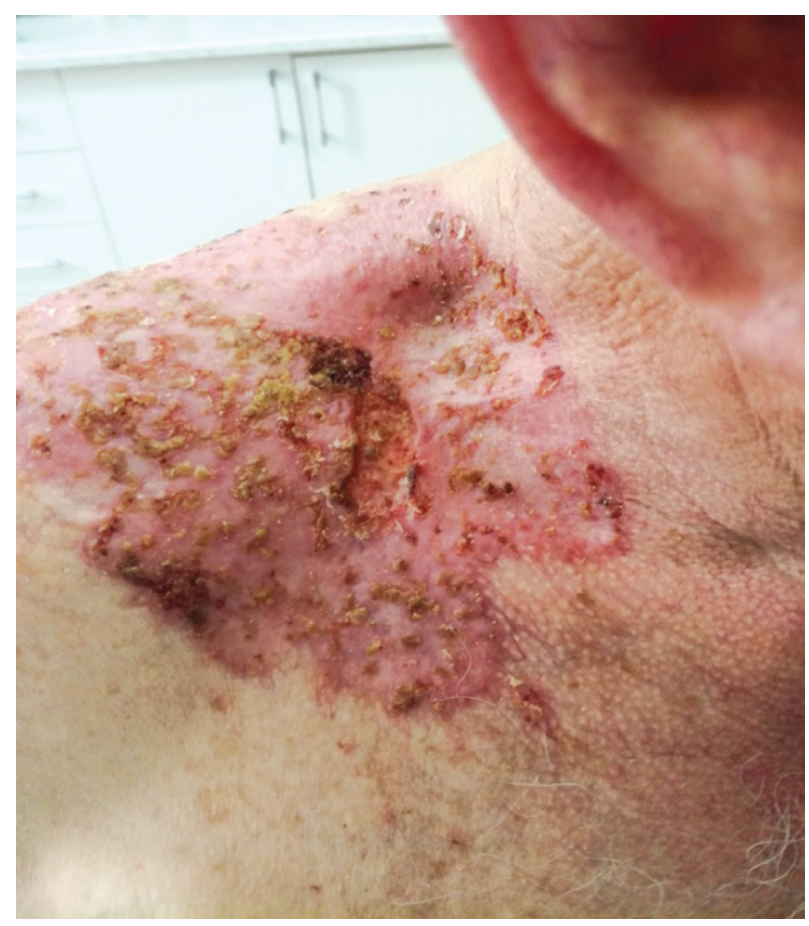

Figure 1. Infiltrative erythematous plaque $17 \mathrm{~cm}$ $x 14 \mathrm{~cm}$. Multiple irregular ulcerations and erosions covered by purulent and hemorrhagic crusts, and without regional lymphadenopathy.

treatment and medical control was ignored by the patient until 2018. On admission, the patient presented with an extensive, well demarcated, oval erythematous, infiltrative plaque $17 \mathrm{~cm} \times 14 \mathrm{~cm}$ in diameter on the right supraclavicular region, with multiple irregular ulcerations and erosions covered by purulent and hemorrhagic crusts, and without regional lymphadenopathy (Figure 1). Anamnestic exploration revealed neither personal nor family history of previous BCC, other skin diseases, radiation or arsenic exposure, sunbathing or previous sunburns. Co-morbidities at presentation included chronic obstructive pulmonary disease, diabetes mellitus type II, hypertension and cardiac arrhythmia.

Routine laboratory analysis, including complete blood count (CBC) revealed elevated sedimentation rate $(94 \mathrm{~mm} / \mathrm{h})$, increased $\mathrm{C}$ reactive protein level $(62.8 \mathrm{mg} / \mathrm{L})$, leukocytosis $\left(16.9 \times 10^{9} / \mathrm{L}\right)$, the decreased number of erythrocytes $\left(3.68 \times 10^{12} / \mathrm{L}\right)$ and decreased level of hemoglobin $(110 \mathrm{~g} / \mathrm{L})$. Biochemistry, urinalysis and tumor markers were within normal limits. Bacterial cultures taken from lesion ulcerations were positive for Staphylococcus aureus. Abdominal ultrasound showed no pathological findings. Since lung x-ray showed a $4.5 \mathrm{~cm} \times 2 \mathrm{~cm}$ oval soft tissue shadow with diffuse bilateral bronchial shadows, a pulmonologist was consulted who required a thoracic multiple detector computed tomography (MDCT) to exclude metastasis and tuberculosis evaluation. Thus, three consecutive sputum samples for Koch bacillus (BK) and Lowenstein cultures were taken and were
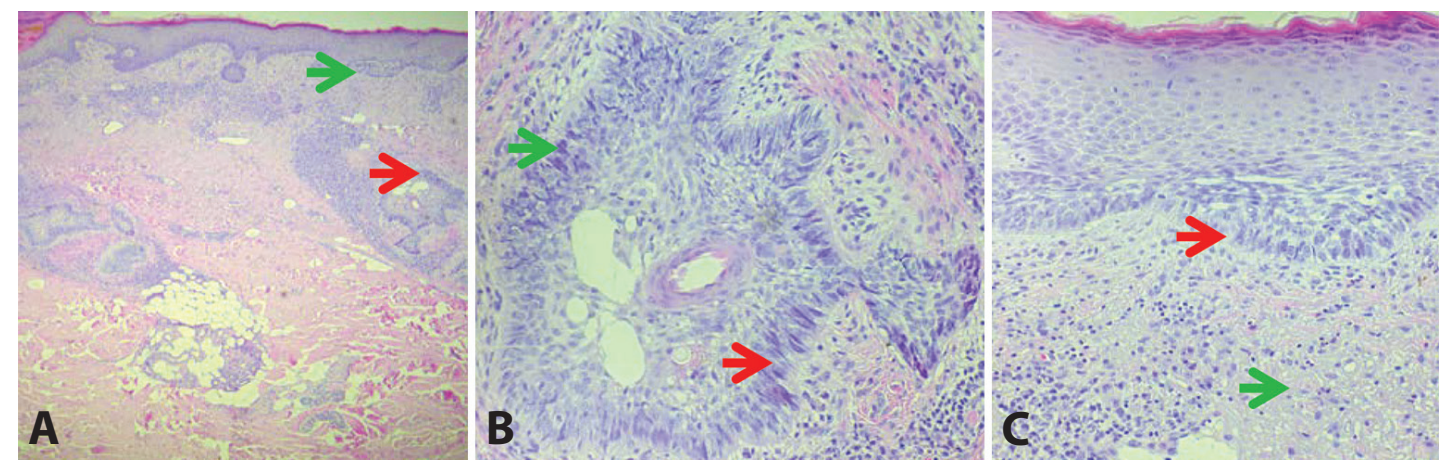

Figure 2.

A) Superficial type of BCC limited to the epidermis with budding pattern $(\rightarrow)$. Focal infiltrative type of BCC $(\rightarrow)$.

B) Infiltrative type of BCC, deeper involvement with irregular tumor nests, palisading arrangement of atypical cells $(\rightarrow)$ showing high nuclear cytoplasm ratio, hyperchromatic nuclei and pleomorphism $(\rightarrow)$.

C) Superficial type of BCC, budding superficial nests of atypical basaloid epithelium confined to the papillary dermis $(\rightarrow)$. Underlying elastosis in dermis $(\rightarrow)$. 


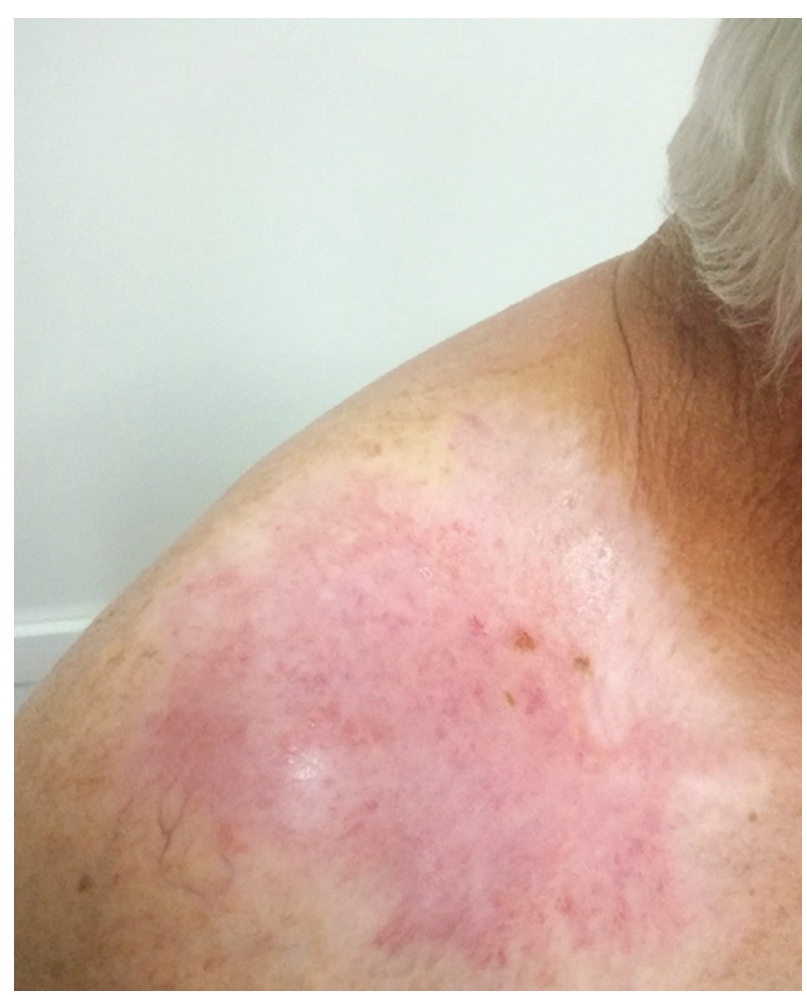

Figure 3. Photo taken 6 months after irradiation. Resolution of ulcerations and lesion spreading. Contraction of the residual paler erythematous plaque with individual telangiectasias along the surrounding white halo like borders.

negative. Thoracic MDCT revealed multiple annular changes in the right upper lobe with active peripheral pyogenic membranes and central, fluid filled cavities with a maximum diameter of $33 \mathrm{~mm}$. Reactive lymph nodes were present in $4 \mathrm{R}$ group of the mediastinum and right hilus. Final diagnosis was abscess pneumonia. Intravenous antibiotics including i.v. Ceftriaxone amp. $1 \mathrm{~g}$ b.i.d, i.v. Levofloxacin amp. $5 \mathrm{mg} / \mathrm{ml}$ b.i.d and i.v. Metronidazole flacc. $500 \mathrm{mg} / 100 \mathrm{ml}$ t.i.d. were administered and resulted in clinical improvement of infection and inflammation. Regression on follow up chest X-ray and MDCT was achieved.

Histological examination of skin lesion confirmed superficial and focally infiltrative types of basal cell carcinoma (Figure 2).

When the patient was presented to the Oncology and Radiology skin and soft tissue specialist committee, his lesion was found to be inoperable and radiotherapy was indicated. The patient was treated with electron radiotherapy consisting of a total dose (TD) of 54 Gy delivered in 20 daily fractions (2.5 Gy/ fraction), with appropriate margins over the course of 20 days. The radiotherapy resulted in resolution of ulcerations and lesion spreading, leading to contraction of the residual paler erythematous plaque, post-irradiation telangiectasias and the surrounding white halo-like borders (Figure 3 ).

After 6 months post-radiotherapy follow up, two biopsies were taken and histopathology revealed post radiation fibrosis with no elements of BCC.

\section{Discussion}

Giant basal cell carcinoma is a rare variant of non-melanoma skin cancer with an epidemiological profile being Caucasian, male gender, and a peak occurrence in the seventh decade. The reported sites of predilection, by a slim margin, were the back $(27.5 \%)$ and face $(23.5 \%)$ with the upper extremities amounting to $13.7 \%$. Rarer cases have been reported on the abdominal wall, genital region, anterior trunk, and lower extremity. One clinicopathological study and

Table 1. BCC and SCC: Recommended fractionation dose schedules (29)

$\begin{array}{lcc}\text { Fractionation dose } & \text { Indication } & \text { Biological effective } \\ \text { Single dose 12-20 Gy fraction- } & \text { Elderly, frail (palliative) } & \\ 7 \text { fractions of } 5 \text { Gy (TD } 35 \mathrm{~Gy}) & \text { Elderly, + medical comorbidity } & 44 \mathrm{~Gy} \\ 10 \text { fractions of } 4 \text { Gy (TD } 40 \mathrm{~Gy}) & \text { Older and healthy } & 47 \text { Gy } \\ 15 \text { fractions of } 3 \text { Gy (45 Gy) } & \text { Older and healthy } & 49 \text { Gy } \\ 20 \text { fractions of } 2.5 \text { Gy (50 Gy) } & \text { Younger and/or <2-3 cm lesion } & 52 \text { Gy } \\ 30 \text { fractions of } 2 \text { Gy (60 Gy) } & \text { Younger and/or large lesion } & 60 \text { Gy }\end{array}$


Table 2. Recommended criteria for radiotherapy (29)

\begin{tabular}{l|c} 
Patients older than 70 years \\
Patient factors & $\begin{array}{c}\text { Patient autonomy: preference to avoid surgery } \\
\text { Anti coagulation and platelet functioning medication } \\
\text { Discernible co-morbidities }\end{array}$ \\
\cline { 2 - 3 } & Site: ala nasi, nasal tip and bridge, lower eyelid, medial canthus, ear \\
Pathological characteristics of tumor & Extensive and superficial size and/or depth \\
& Complex surgery required for locally advanced stage
\end{tabular}

review of literature concluded the mean size to be $14.77 \mathrm{~cm}$, ranging from 5 to $40 \mathrm{~cm}$. The reported total duration of the tumor presence was 14.57 years on average (9).

Clinically, GBCC has been reported as the following subtypes: nodular-ulcerative (10), vegetant/exophytic (11), extensively ulcerative (12), morpheaform (13), and polypoid (14). Naturally, they are more likely to invade the extradermal structures due to their size and years of growth, thus potentially causing cosmetic deformations. Invasion of the underlying cartilage, soft tissue, and bone was not seen in our patient during the workup.

In terms of histology, there are differences between conventional sized BCCs and GBCCs. Purnell et al. published a review of 57 cases comparing the histological differences contributing to excessive growth. Besides size, GBCCs were thicker, with higher incidence of ulcerations, and possessed a more infiltrative growth than conventional BCC, but the authors concluded that histological features alone were unlikely to be the reason for the large clinical size (15). Up to 27 histological subtypes of basal cell carcinoma have been reported (16). The histological subtype is an important factor that leads to the progression and formation of GBCCs, and they can be broadly categorized as non-aggressive and aggressive. Non-aggressive one includes superficial and nodular, while aggressive GBCC includes metatypical, micronodular and morpheaform subtypes. Archontaki et al. reported that $54 \%$ of GBCCs reviewed were histologically nodular, $19 \%$ infiltrating, $9.5 \%$ were metatypical or morpheaform, and only $4.76 \%$ were accounted as superficial spreading (9). On the other hand, in a study of 50 patients with GBCC by Randle et al., $72 \%$ were classified as infiltrative or micronodular. Finally, the World Health Organization (WHO) classification, currently in use, only recognizes the following subtypes: nodular, superficial, micronodular, infiltrating, sclerosing/morphoeic, basosquamous, pigmented, BCC with sarcomatoid differentiation, BCC with adnexal differentiation, and fibroepithelial, which leads to improved clarity and reproducibility (17).

Metastasis is a rare complication of conventional, mostly indolent, BCC as it spreads more horizontally rather than vertically. According to the literature, there have been roughly 300 cases reported (18), with an estimated incidence rate of $0.0028 \%$ to $0.5 \%(19$, $20)$. Mean time interval from tumor onset to metastasis is roughly 9 years and only half of the patients survive 8 months after the beginning of metastatic symptoms (21). In a published review, Randle et al., concluded that BCCs larger than $2 \mathrm{~cm}$ in diameter, located on the ear or mid face, with aggressive histopathological type, previous treatment and, history of neglect or radiation have a higher propensity for potential metastasis (22). A positive correlation of the tumor size and metastatic potential has been established. Tumors larger than $3 \mathrm{~cm}, 5 \mathrm{~cm}$ and $10 \mathrm{~cm}$ in diameter increase the incidence of metastasis to $2 \%, 25 \%, 50 \%$ respectively (23). All of these factors apply to GBCC making it essential to rule out metastasis in patients. In fact, most cases of metastatic BCCs are in fact GBCC. Archontaki et al. reported that metastasis was present in $17.6 \%$ of GBCC patients during the primary examination (9). Contrary to the general belief, multiple studies have confirmed that there is no correlation between specific histopathological subtype of BCC with a high- 
er incidence of metastasis (24). The most common sites of metastasis are lymph nodes, lung and bone, but there are individual documented cases of hematogenous spread to other organs. Despite a detailed work-up, we did not find any signs of metastasis in our patient.

There are no specific guidelines for treating GBCC or metastatic disease. Wide surgical excision with free margins remains the preferred treatment of choice for GBCC, as well as for BCC. In general, BCCs less than 1 $\mathrm{cm}$ implement margins 2-4 $\mathrm{mm}$ achieving a 5 -year cure rate of $95 \%$ (3). Larger lesions require clinical margins of $3-5 \mathrm{~mm}$ due to subclinical extension. Other potential treatment options include immunomodulators (25), topical chemotherapeutic agents (25), photodynamic therapy (26), biological therapy (Vismodegib, a sonic hedgehog pathway inhibitor, FDA approved in advanced cases and metastasis, $150 \mathrm{mg}$ once daily) (8), Mohs micrographic surgery, and radiotherapy, whether definitive or adjuvant. In general, surgery and radiotherapy are the most effective treatment options (27). The risk of tumor residue in GBCC post excision has been reported to be $68 \%$ (13). When the tumor is inoperable or surgery is contraindicated in an elderly patient, as it was in our patient, radiotherapy is an appropriate alternative. In general, radiotherapy can be administered by using linear accelerators for high-energy X-rays, or by electron radiotherapy (regularly preferred due to the accurate prescription of used energy for depth of penetration) for many clinical applications including GBCC. There is a high degree of variation in fractionation regimes in non-melanoma skin cancers. According to one survey done in the United Kingdom (UK), the four most common regimes used were (18-20 Gy in 1 fraction, 35 Gy in 5 fractions, $45 \mathrm{~Gy}$ in 10 fractions and $55 \mathrm{~Gy}$ in 20 fractions) (28). Other dosing fractions suggested in literature are included in Table 1. Guidelines for BCC state $0.5 \mathrm{~cm}$ deep margins and lateral margins to be $0.5 \mathrm{~cm}$ (morphoeic, large, infiltrative or poorly defined require $0.7 \mathrm{~cm}-1 \mathrm{~cm}$ ) with an additional 0.5 to $1 \mathrm{~cm}$ for electron therapy to account for penumbra of electrons (30). Factors and tumor specificities indicating radiotherapy as the treatment option are presented in Table 2. There is a correlation between greater tumor size and depth, with a decrease in local cure rates. Regular followup is required since currently there are no guidelines suggesting when to take a control biopsy to rule out post radiotherapy BCC recurrence. Early detection and adequate, timely treatment remain imperative in preventing recurrence and metastasis.

\section{Conclusion}

Giant basal cell carcinoma is a rare subtype of BCC that requires a thorough work up and can lead to difficulties in choosing the appropriate treatment. Patient awareness needs to be increased as timely medical consultation is essential for the treatment success. When the criteria are met, definitive radiotherapy can be just as effective and therefore it is an adequate alternative to surgical excision. Since there is a lack of guidelines for GBCC treatment criteria, follow up and radiotherapy dose fractionation schedules, they should be provided as soon as possible.

\section{Acknowledgment}

This study was supported by the Fund of The Serbian Ministry of Health, Education and Technological development (Grant No. 175038 and 175026).

\section{Abbreviations}

Amp. - Ampule

BCC - Basal Cell Carcinoma

CBC - Complete Blood Count

FDA - Food and Drug Administration

GBCC - Giant Basal Cell Carcinoma

Gy - Gray

MDCT - Multidetector computed tomography

TB - Tuberculosis

TD - Total dose

UK - United Kingdom

WHO - World Health Organization

\section{References}

1. Lorenzini M, Gatti S, Giannitrapani A. Giant basal cell carcinoma of the thoracic wall: a case report and review of the literature. Br J Plast Surg. 2005;58(7):1007-10. 
2. Dessinioti C, Antoniou C, Katsambas A, Stratigos AJ. Basal cell carcinoma: what's new under the sun. Photochem Photobiol. 2010;86(3):481-91.

3. Gulleth Y, Goldberg N, Silverman RP, Gastman BR. What is the best surgical margin for a basal cell carcinoma: a meta-analysis of the literature. Plast Reconstr Surg. 2010;126(4):1222-31.

4. Beahrs OH, Henson DE, Hutter RVP, Myers MH. American Joint Committee on Cancer. Manual for staging of cancer. 3rd ed. Philadelphia: Lippincott; 1988.

5. Betti R, Inselvini E, Moneghini L, Crosti C. Giant basal cell carcinomas: report of four cases and considerations. J Dermatol. 1997;24(5):317-21.

6. SahI WJ Jr, Snow SN, Levine NS. Giant basal cell carcinoma. Report of two cases and review of the literature. J Am Acad Dermatol. 1994;30(5 Pt 2):856-9.

7. Arnaiz J, Gallardo E, Piedra T, Sanz-Jimenez-Rico J, Trillo Bohajar E, Alonso Pena D. Giant basal cell carcinoma on the lower leg: MRI findings. J Plast Reconstr Aesthet Surg. 2007;60(10):1167-8.

8. Desmond B, Boudreaux L, Young J. A rare case of super giant basal cell carcinoma. JAAD Case Rep. 2015; (5):280-2.

9. Archontaki M, Stavrianos SD, Korkolis DP, Arnogiannaki N, Vassiliadis V, Liapakis IE, et al. Giant basal cell carcinoma: clinicopathological analysis of 51 cases and review of the literature. Anticancer Res. 2009;29(7):2655-63.

10. Gundalli S, Kolekar R, Kolekar A, Nandurkar V, Pai K, Nandurkar S. Study of basal cell carcinoma and its histopathological variants. Our Dermatology Online. 2015;6(4):399-403.

11. Manstein $\mathrm{CH}$, Manstein ME, Beidas OE. Giant basal cell carcinoma: 11-year follow-up and seven new cases. Plast Reconstr Surg. 2011;128(5):1105-6.

12. Ko C, Walton S, Keczkes K. Exxtensivive and fatal b basal cell carcinoma: a report of three cases. $\mathrm{Br} J$ Dermatol. 1992;127(2):164-7.

13. Randle HW, Roenigk RK, Brodland DG. Giant basal cell carcinoma (T3). Who is at risk? Cancer. 1993;72(5):1624-30.

14. Handjani F, Shahbaz S, Sari-Aslani F, Aghaei S, AliZadeh AA. A giant polypoid_basa the lower extremity. Arch Iran Med. 2010;13(2):153-5.

15. Purnell JC, Gardner JM, Brown JA, Shalin SC. Conventional versus giant basal cell carcinoma, a review of 57 cases: histologic differences contributing to excessive growth. Indian J Dermatol. 2018;63(2):147-54.
16. Anwar U, Al Ghazal S, Ahmad M, Sharpe D. Horrifying basal cell carcinoma forearm lesion leading to shoulder disarticulation. Plast Reconstr Surg. 2006;117(1):6e-9.

17. LeBoit PE, Burg G, Weedon D, Sarasin A. World Health Organization classification of tumors. Pathology and genetics of skin tumors. Lyon: IARC Press; 2006. p. 10-33.

18. Wadhera A, Fazio M, Bricca G, Stanton O. Metastatic basal cell carcinoma: a case report and literature review. How accurate is our incidence data? Dermatol Online J. 2006;12(5):7.

19. Lattes R, Kessler RW. Metastasizing basal-cell epithelioma of the skin: report of two cases. Cancer. 1951;4(4):866-78.

20. Mohan SV, Chang Al. Advanced basal cell carcinoma: epidemiology and therapeutic innovations. Curr Dermatol Rep. 2014;3(1):40-5.

21. Von Domarus H, Stevens PJ. Metastatic basal cell carcinoma. Report of five cases and review of 170 cases in the literature. J Am Acad Dermatol. 1984;10(6):1043-60.

22. Randle HW. Basal cell carcinoma. Identification and treatment of the high-risk patient. Dermatol Surg. 1996;22(3):255-61.

23. Snow SN, Sahl W, Lo JS, Mohs FE, Warner T, Dekkinga JA, et al. Metastatic basal cell carcinoma. Report of five cases. Cancer. 1994;73(2):328-35.

24. Wermuth BM, Fajardo LF. Metastatic basal cell carcinoma. A review. Arch Pathol. 1970;90(5):458-62.

25. Love WE, Bernhard JD, Bordeaux JS. Topical imiquimod or fluorouracil therapy for basal and squamous cell carcinoma: a systematic review. Arch Dermatol. 2009;145(12):1431-8.

26. Morton CA, McKenna KE, Rhodes LE. Guidelines for topical photodynamic therapy: update. $\mathrm{Br} J$ Dermatol. 2008;159(6):1245-66.

27. Bath-Hextall FJ, Perkins W, Bong J, Williams HC. Interventions for basal cell carcinoma of the skin. Cochrane Database Syst Rev. 2007;(1):CD003412.

28. McPartlin AJ, Slevin NJ, Sykes AJ, Rembielak A. Radiotherapy treatment of non-melanoma skin cancer: a survey of current UK practice and commentary. $\mathrm{Br} J$ Radiol. 2014;87(1043):20140501.

29. Veness M, Richards S. Radiotherapy. In: Bolognia JL, Schaffer JV, Cerroni LL, editors. Dermatology. Vol. 2. 4th ed. Amsterdam: Elsevier; 2017. p. 2393-403.

30. Anand G. Skin Cancer Radiotherapy Guidelines [Internet]. London: London Cancer; 2013 [cited 2018 Oct 21]. Available from: http://www.londoncancer.org/me$\mathrm{dia} / 76382 /$ Iondon-cancer-skin-radiotherapy-guidelines-2013-v1.0.pdf. 


\section{Bazocelularni karcinom - prikaz slučaja}

\section{Sažetak}

Bazocelularni karcinom je najčešći oblik karcinoma kože. U većini slučajeva je lokalno invazivan sa sporim rastom koji može da varira od nekoliko milimetara do nekoliko centimetara sa predominantnom lokalizacijom na fotoeksponiranim regijama. U retkim slučajevima, $0,5-1 \%$, dimenzije bazocelularnog karcinoma mogu prevazići i $5 \mathrm{~cm}$ i tada se klasifikuje kao gigantski bazocelularni karcinom. Lezije ovakve veličine mogu dovesti do teškoća u izboru odgovarajućeg tretmana. Predstavljamo slučaj 74-godišnjeg muškarca sa gigantskim bazocelularnim karcinomom u predelu desnog ramena, dimenzija $14 \mathrm{~cm}$ x $17 \mathrm{~cm}$ koji se pojavio 2003 . godine. lako se lezija konstantno uvećavala, pacijent se do 2018. godine nije javio na pregled. Histopatološkim nalazom dijagnostikovan je bazocelularni karcinom - superficijalni, fokalno infiltrativni tip. Nakon toga je uvedena zračna terapija elektronima, sa 54 Gyu 20 dnevnih seansi što je dovelo do adekvatnog odgovora. Ovim prikazom želimo da naglasimo da kada su ispunjeni kriterijumi, radioterapija može biti efikasna terapija koliko i hirurgija kod gigantskog bazocelularnog karcinoma.

Ključne reči: Bazocelularni karcinom; Dijagnoza; Metastaze; Koža; Radioterapija; Biopsija; Ishod Terapije; Prikazi Slučajeva

Received 5 November, 2018

Accepted 3 December, 2018 